\title{
A Review of the Utilisation of Natural Gas with High Carbon Dioxide Content as Automotive Fuel in an Indirect Injection Diesel Engine
}

\author{
Rasheed Adewale Opatola ${ }^{1, \mathrm{a}}$, A. Rashid A. Aziz ${ }^{2}$, Morgan Raymond Heikal ${ }^{3}$, Mior Azman Meor \\ Said ${ }^{4}$ \\ ${ }_{1,2,3,4}$ Department of Mechanical Engineering, University Teknologi PETRONAS, Bandar Seri \\ Iskandar, 31750 Tronoh, Perak, Malaysia
}

\begin{abstract}
The persistent consumption of fossil fuels by modern transportation tends toward feared depletion in crude oil and infliction of health risks on human beings and the environment due to the noxious emissions from the combustion of fossil fuels. This work examines the prospects of fuel modification in improving engine performance by utilising compressed natural gas $(\mathrm{CNG})$ mixed with varying proportions of carbon dioxide $\left(\mathrm{CO}_{2}\right)$ as fuel in Diesel engines. The extent to which the addition of $\mathrm{CO}_{2}$ to $\mathrm{CNG}$ could help simulate the effects of exhaust gas recirculation (EGR) as employed in modern engine technology will be established.
\end{abstract}

Keywords: indirect injection, compressed natural gas, $\mathrm{CO}_{2}$, engine performance, emissions

\section{Introduction}

Although Diesel engines are the most reliable and fuel-efficient internal combustion engines in the automotive industry; its high emissions drawbacks and the rising cost of fossil fuels have elicited concerns among automotive engineers. In response to health issues, the European Union has introduced stringent emission standards to regulate atmospheric pollutants such as PM, NOx and HC for vehicles sold in the EU market [1]. Consequently, the past decades have witnessed upsurges in modern engine technology, which are aimed at utilising alternative fuels and hence, abating emissions from Diesel engines, such as advanced fuel injection equipment, piezo-injection, injector nozzle modification, after-treatment devices and etc. [2]-[6]. However, in spite of encouraging results, these technologies come with high price tags; the cost and complexity in retrofitting them in to existing engines, therefore, threaten the competitiveness of the Diesel engine package.

Further advances in modern engine technology have led to the emergence of the low temperature combustion techniques, which are aimed at improved fuel consumption and reduced emissions through modification of combustion processes [7]. These include homogeneous charge compression ignition (HCCI) [8]-[10], premixed charge compression ignition (PCCI) [5], [11], [12], partially premixed charge compression ignition (PPCI) engines [13] and EGR [14], [15]. HCCI and PCCI engines demonstrate pronounced capabilities in terms of simultaneous ultra-low NOx and PM emissions.

\footnotetext{
${ }^{\text {a }}$ Corresponding author : surulere_opatola@hotmail.com
}

This is an Open Access article distributed under the terms of the Creative Commons Attribution License 2.0, which permits unrestricted use, distribution, and reproduction in any medium, provided the original work is properly cited. 
However, HCCI engines are inhibited by obstacles such as combustion control, high $\mathrm{HC}$ and $\mathrm{CO}$ emissions at low loads, increase in NOx emission at high loads, high rates of heat release and etc. [5], [14], [16]-[18]. PCCI, on other hand, is difficult to achieve at high engine loads; this fact combined with cold start challenges and the higher $\mathrm{CO}$ and $\mathrm{HC}$ emissions have resulted in the use of catalysts in PCCI operation [19]. In spite of the retinue of advancements in research over the last decade, large scale adoption of HCCI Diesel engines in commercial vehicles is presently not feasible [20].

Recently, dual-fuel combustion techniques, which often consider modification of the fuel itself in controlling combustion processes, and hence engine-out emissions, have elicited varied investigations and applications. For instance, studies have revealed that, in addition to improved fuel economy, the dual-fuel combustion concept utilising CNG/Diesel is found supportive in the mitigation of pollutant emissions from Diesel engines [21]-[23]. Usually, a carburetted mixture of air and high octane gaseous fuel (e.g. natural gas), prepared in an external mixing device, is compressed and inducted into the engine cylinders. The compressed mixture of air and natural gas does not auto-ignite due to its high auto-ignition temperature. Therefore, a pilot amount of diesel fuel is injected into the cylinders near the top dead centre (TDC) of the compression stroke. After a short ignition delay, the combustion of diesel occurs first; igniting the natural gas, and then the flame propagation begins. The presence of compressed natural gas $(\mathrm{CNG})$ in the charge reduces the cylinder temperature due to lean combustion, which subsequently results in lower NOx and PM emissions. Hence, this work examines the prospects of fuel modification in improving engine performance and abating engine-out emissions, by utilising compressed natural gas $(\mathrm{CNG})$ mixed with varying proportions of carbon dioxide $\left(\mathrm{CO}_{2}\right)$ as fuel in Diesel engines.

\section{CNG-CO2/Diesel dual-fuel combustion}

As aptly expressed by [23], dual-fuel combustion, using CNG/Diesel as base fuel, is currently restored in the exertion to overcome the difficulties of HCCI engines, $\mathrm{NO}_{\mathrm{x}}, \mathrm{PM}$ and $\mathrm{CO}$ emissions, which is really difficult to achieve in Diesel engines. The technique reduces the quantity of diesel consumption and hence, results in cleaner combustion due to the low $\mathrm{C} / \mathrm{H}$ ratio [24]. Extensive researches have revealed that substitution of diesel fuel by natural gas, under dual-fuel mode, yield lower peak cylinder pressure, lesser brake specific fuel consumption $(b s f c)$ and reduced $\mathrm{NO}_{\mathrm{x}}, \mathrm{CO}_{2}$ and $\mathrm{PM}$ emissions when compared to normal diesel combustion with some trade-off in emission levels of $\mathrm{CO}$ and HC [23].

Gharehghani et al. [25] reported that by increasing the intake swirl ratio in dual-fuel engines, a significant reduction in $\mathrm{NO}_{\mathrm{x}}$ was achieved at high engine load with lower mass ratio of natural gas, while lower PM was recorded at lower load and higher mass ratio of natural gas. At part load, the total $b s f c$ was considerably higher under dual-fuel mode due to the low combustion rate of gaseous fuel. However, at lower loads, both emission and combustion performance suffered due to the extremely lean mixture and incomplete combustion in the dual-fuel mode. To resolve the light load performance problem, [26] introduced 15\% cooled EGR into a dual-fuel Diesel engine, which led to visible reduction in the exhaust emissions of $\mathrm{NO}_{x}, \mathrm{CO}$ and $\mathrm{HC}$. Although it helps to noticeably reduce $\mathrm{NO}_{\mathrm{x}}$ emissions, EGR has certain shortcomings in Diesel engines. The drop in oxygen and overall temperature favours the release of unburned $\mathrm{HC}$ and $\mathrm{CO}$; hence, it mitigates $\mathrm{NO}_{\mathrm{x}}$ emissions at the expense of rise in the emissions of $\mathrm{HC}, \mathrm{CO}$ and PM [27]. Moreover, there is a bound to EGR technology, which is about $35 \%$, necessitating further treatment of exhaust gases in order to keep pace with emissions standards.

Furthermore, $\mathrm{CO}_{2}$ was used in simulating the effects of EGR by [28]. Their findings showed that $\mathrm{CO}_{2}$ addition was suitable in extenuating $\mathrm{NO}_{\mathrm{x}}$ and soot emissions and the cost of EGR cooling system. Jin et al [29] used four different $\mathrm{CO}_{2}$ mass fractions in diesel fuel, namely, 3.13\%, 7.18\%, 12.33\% and $17.82 \%$ to study the effect of $\mathrm{CO}_{2}$ concentration on jet flame characteristics. They reported that the dilution and atomisation effects of the dissolved $\mathrm{CO}_{2}$ component in the fuel had a great influence on the flame structure. At the same injected pressure, the low temperature flame length increased with increase in $\mathrm{CO}_{2}$ concentration in the fuel and vice-versa. The mean temperature of the flame increased 
and then dropped with increase in $\mathrm{CO}_{2}$ concentration at the same injected pressure. In a related work, the effects of in-cylinder injection of $\mathrm{CO}_{2}$ on PCCI combustion were investigated by [30]. They found that for in-cylinder injection of $\mathrm{CO}_{2}$, either advancing $\mathrm{CO}_{2}$ injection timing or increasing cyclic injection quantity greatly reduced the emission of $\mathrm{NO}_{\mathrm{x}}$ with little loss in the thermal efficiency. With increase in the $\mathrm{CO}_{2}$ injection quantity, intake pipe injection had a similar effect to EGR, that is, reduction in $\mathrm{NO}_{\mathrm{x}}$ and increase in $\mathrm{PM}$ emission [30].

Moreover, Çinar et al [31] investigated the effect of $\mathrm{CO}_{2}$ as a diluent in the intake manifold and injection pressure on engine torque, power, bmep, specific fuel consumption $(s f c), \mathrm{CO}, \mathrm{PM}$ and $\mathrm{NO}_{\mathrm{x}}$ emissions. In this study, $\mathrm{CO}_{2}$, used as diluent, was injected into the intake manifold of a Diesel engine at a ratio of $2 \%, 4 \%$ and $6 \%$ respectively. The research outcomes revealed that while $\mathrm{NO}_{\mathrm{x}}$ emission improved with $\mathrm{CO}_{2}$ admission in the inlet charge, other parameters deteriorated. With $6 \% \mathrm{CO}_{2}$ admission, engine torque, power, bmep and $b s f c$ approximately deteriorated by $5.9 \%, 5.5 \%, 6 \%$, and $3.3 \%$ respectively; smoke emission increased approximately by $60 \%$ while $\mathrm{CO}$ emission increased approximately by 8.5 times from its base level. In spite of all these, $\mathrm{NO}_{\mathrm{x}}$ emission reduced approximately by $50 \%$ at $6 \%$ admission of $\mathrm{CO}_{2}$. In the work of Bedoya et al. [32], the effects of mixing system and the pilot fuel quality on performance using biogas $\left(60 \% \mathrm{CH}_{4}+40 \% \mathrm{CO}_{2}\right)$ as primary fuel in a stationary, dual-fuel Diesel engine were investigated. Their findings revealed that full diesel substitution was attainable using biogas and biodiesel as power sources for all loads evaluated. Thermal efficiency and substitution of pilot fuel were increased, while $\mathrm{CH}_{4}$ and $\mathrm{CO}$ emissions were reduced by using supercharged mixing system combined with biodiesel as pilot fuel.

\section{Inferences from literature}

Inferences from literature revealed that existing literature and data on combustion, performance, incylinder pressure and temperature; rate of heat release; emissions and other parameters characterising CNG- $\mathrm{CO}_{2}$ /Diesel dual-fuel combustion in Diesel engine are inadequate. Natural gas, a clean fuel, possesses impressive tolerance for high compression without resultant knocking in IC engines. On the other hand, the heat absorbing capacity of $\mathrm{CO}_{2}$ makes it a good diluent, which lowers in-cylinder temperature and pressure, the major precursor of $\mathrm{NO}_{\mathrm{x}}$ emissions, during combustion. Hence, $\mathrm{CNG}$ is intended at minimising emissions, which are directly related to the combustion of diesel fuel, while the addition of $\mathrm{CO} 2$ acts as EGR. Depending on the engine speed and load, CNG appreciably influences engine performance and emissions. The effect of increasing EGR in Diesel engine on the resultant NOx and PM emissions was discussed in [33] as illustrated in Figure 1. The large amount of soot in higher EGR percentage was attributed to lower performance due to reduction in oxygen concentration, and soot accumulation due to the recirculation of exhaust gas through many cycles as well. The possibility, therefore, exists that subject to the fine tuning of the various parameters influencing engine operation, $\mathrm{CNG}-\mathrm{CO}_{2}$ replacing as fuel in a Diesel engine could well achieve improved fuel efficiency and equally discharge the roles of EGR, with tolerable compromise in performance. Expectedly, reductions in $\mathrm{NO}_{\mathrm{x}}$ emissions may be achieved; while PM emissions could also be reduced.

\section{The natural gas deposits in Malaysia and $\mathrm{CNG}-\mathrm{CO}_{2} / \mathrm{Diesel}$ engine combustion}

The natural gas deposits in Malaysia is characterised as sour because of the high $\mathrm{CO}_{2}$ content, which is in the range of $12-40 \%$ by chemical composition [34]; hence, they are not readily exploitable in automobiles as the high $\mathrm{CO}_{2}$ content can significantly retard in-cylinder temperature and pressure, with attendant adverse effects on engine performance. Undoubtedly, capturing $\mathrm{CO}_{2}$ from natural gas is a capital intensive venture. Hence, arising from the high cost of capturing $\mathrm{CO}_{2}$ from natural gas and the perennial engine emissions, modifying the morphology of Diesel engine that can accommodate the usage of untreated natural gas appears to be a cheaper alternative. The possibility, therefore, exists that 
subject to the fine tuning of the various parameters influencing engine operation, $\mathrm{CNG}-\mathrm{CO}_{2} / \mathrm{Diesel}$ as fuel in a Diesel engine could function well as automobile fuel with tolerable compromise in performance. Furthermore, the high heat absorbing capacity of $\mathrm{CO}_{2}$ reduces oxygen concentration and thus, lowers in-cylinder temperature, the major precursor of $\mathrm{NO}_{\mathrm{x}}$ emissions during combustion.

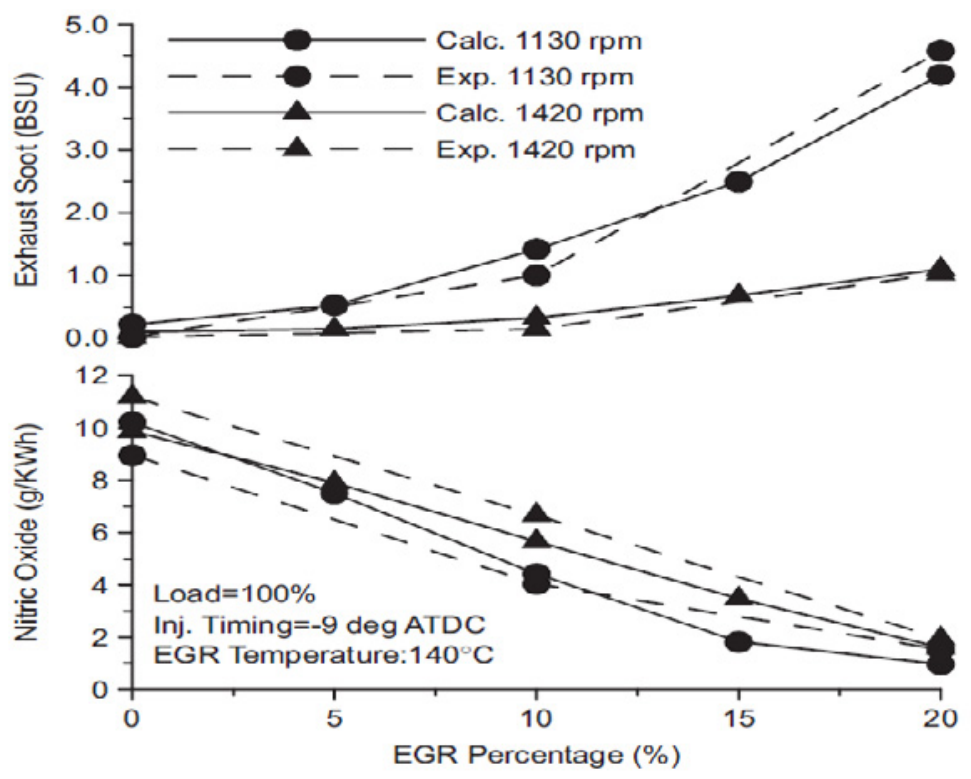

Figure 1. Effect of EGR rate on calculated and measured NO and soot emissions [33]

\section{Materials and methods}

A four-cylinder IDI Diesel engine will have its intake port modified to accommodate the injection system for CNG-CO $\mathrm{CO}_{2}$ gases. The $\mathrm{CNG}$ and $\mathrm{CO}_{2}$, from separate cylinders at different proportions, will be mixed in a fuel mixing chamber and injected into the cylinder through the intake port of the engine. As the charge is compressed in the cylinder, a pilot amount of diesel will be injected near the end of compression stroke to initiate ignition. The brake specific fuel consumption (bsfc) and the cylinder pressure history, will be identified directly from the engine control unit. Other engine parameters to be studied are NOx, CO, unburned HC, and total particulate matter (PM). Engine performance analysis would be carried out for specified engine speeds and loads in three different operation modes. The normal diesel combustion analysis tests will be taken as baseline performance data for the comparison and analysis of the other two modes.

\section{Conclusion}

Although the dual-fuel application on Diesel engine using CNG as fuel with pilot diesel injection is known, adding $\mathrm{CO}_{2}$ to the system to improve fuel economy and mitigate emissions is yet to be fully exploited. The natural gas, with $\mathrm{CO}_{2}$ addition, could replace a significant portion of the diesel fuel; and possibly, result in lower brake specific fuel consumption (bsfc) value. This concept can be applied on existing engines which do not have EGR system to mitigate emissions with improved or at least maintained fuel efficiency comparable to the conventional Diesel engine since the presence of $\mathrm{CO}_{2}$ in the CNG simulates the effects of EGR. Moreover, it avoids the use of cooling unit and the problem of growing soot concentration in subsequent cycles since it is cleaner than EGR. Furthermore, it is 
expected that the high cost associated with the capture of $\mathrm{CO}_{2}$ from natural gas could be eliminated since this concept employs $\mathrm{CNG}$ with substantial $\mathrm{CO}_{2}$ content. Ultimately, a breakthrough in experimental work may trigger the mass utilisation of the abundant natural gas deposit in Malaysia in its raw form, which has for long remained mostly untapped.

\section{References}

1. The European Union, “Commission Regulation (EC) No. 692/2008, Off. J. Eur. Union, L 199, 1135. (2008).

2. M. Bergmann, U. Kirchner, R. Vogt, and T. Benter, Atmos. Environ. 43, 1908-1916 (2009)

3. R. Caprotti, A. Breakspear, and O. Graupner, SAE Tech. ... 2006-01-33, (2006)

4. H. Iizuka, M. Kaneeda, N. Shinotsuka, O. Kuroda, K. Higashiyama, and A. Miyamoto, Appl. Catal. B Environ. 95, 320-326 (2010)

5. O. Laguitton, C. Crua, T. Cowell, M. R. Heikal, and M. R. Gold, Energy Convers. Manag. 48, 2918-2924 (2007)

6. H. K. Suh, S. W. Park, and C. S. Lee, Fuel 86, 2833-2845 (2007)

7. J. E. Dec, Proc. Combust. Inst. 32, 2727-2742 (2009)

8. M. Ghazikhani, M. R. Kalateh, Y. K. Toroghi, and M. Dehnavi, Int. J. Aerosp. Mech. Eng. 4, 81$87(2010)$

9. K. Kobayashi, T. Sako, S. Morimoto, S. Kanematsu, K. Suzuki, T. Nakazono, and H. Ohtsubo, J. Nat. Gas Sci. Eng. 3, 651-656 (2011)

10. R. J. Osborne, G. Li, S. M. Sapsford, J. Stokes, T. H. Lake, and M. R. Heikal, SAE 2003-01-0750, $2003(2003)$

11. H. Kim, Y. Kim, and K. Lee, Energy \& Fuels 22, 1542-1548 (2008)

12. R. Kiplimo, E. Tomita, N. Kawahara, and S. Yokobe, Appl. Therm. Eng. 37, 165-175 (2012)

13. A. Nemati, R. Barzegar, A. Khalil, and H. Khatamnezhad, Therm. Sci. 15, 939-952 (2011)

14. S. Khalilarya, S. Jafarmadar, H. Khatamnezhad, G. Javadirad, and M. Pourfallah, Int. J. Aerosp. Mech. Eng. 6, 26-34 (2012)

15. H. Machrafi, S. Cavadias, and J. Amouroux, Energy 35, 1829-1838 (2010)

16. X.-C. Lü, W. Chen, and Z. Huang, Fuel 84, 1084-1092 (2005)

17. J. Ma, X. Lü, L. Ji, and Z. Huang, Int. J. Therm. Sci. 47, 1235-1242 (2008)

18. M. Yao, Z. Zheng, and H. Liu, Prog. Energy Combust. Sci. 35, 398-437 (2009)

19 J. E. Parks, V. Prikhodko, J. M. E. Storey, T. L. Barone, S. a. Lewis, M. D. Kass, and S. P. Huff, Catal. Today 151, 278-284 (2010)

20. S. Gan, H. K. Ng, and K. M. Pang, Appl. Energy 88, 559-567 (2011)

21. A. Ibrahim and S. Bari, Energy \& Fuels 23, 4949-4956 (2009)

22. M. A. Kalam and H. H. Masjuki, Energy 36, 3563-3571 (2011)

23. R. G. Papagiannakis and D. T. Hountalas, Energy Convers. Manag. 45, 2971-2987 (2004)

24. R. Singh and S. Maji, Int. J. Eng. Sci. 4, 833-846 (2012)

25. A. Gharehghani, S. M. Mirsalim, and S. A. Jazayeri, J. Combust. 2012, 1-10 (2012)

26. V. Pirouzpanah and R. K. Sarai, Proc. Inst. Mech. Eng. Part D J. Automob. Eng. 217, 719-725 (2003)

27. V. Peixoto, C. Argachoy, I. Trindade, and M. Airoldi, Fourth Eur. Combust. Meet. Vienna (2009)

28. H. Zhao, J. Hu, and N. Ladommatos, Proc. Inst. Mech. Eng. Part D J. Automob. Eng. 214, 405419 (2000)

29. X. Jin, H. Zhen, Q. Xinqi, and H. Yuchun, Fuel 87, 395-404 (2008)

30. S. Qu, K.-Y. Deng, Y. Cui, and L. Shi, Proc. Inst. Mech. Eng. Part D J. Automob. Eng. 222, 1501-1511 (2008)

31. C. Çinar, T. Topgül, M. Ciniviz, and C. Haşimoğlu, Appl. Therm. Eng. 25, 1854-1862 (2005)

32. I. D. Bedoya, A. A. Arrieta, and F. J. Cadavid, Bioresour. Technol. 100, 6624-6629 (2009)

33. D. T. Hountalas, G. C. Mavropoulos, and K. B. Binder, 19th Int. Conf. Effic. Cost, Optim. Simul. Environ. Impactof Energy Syst. ECOS 2006 33, 272-283 (2008)

34. Gas Malaysia Sdn. Bhd. The Future of the Gas Industry in Malaysia. [Online]. Available: http://www.gasmalaysia.com/about_gas/future_gas_industry.htm. [Accessed: 02-Mar-2014]. 